

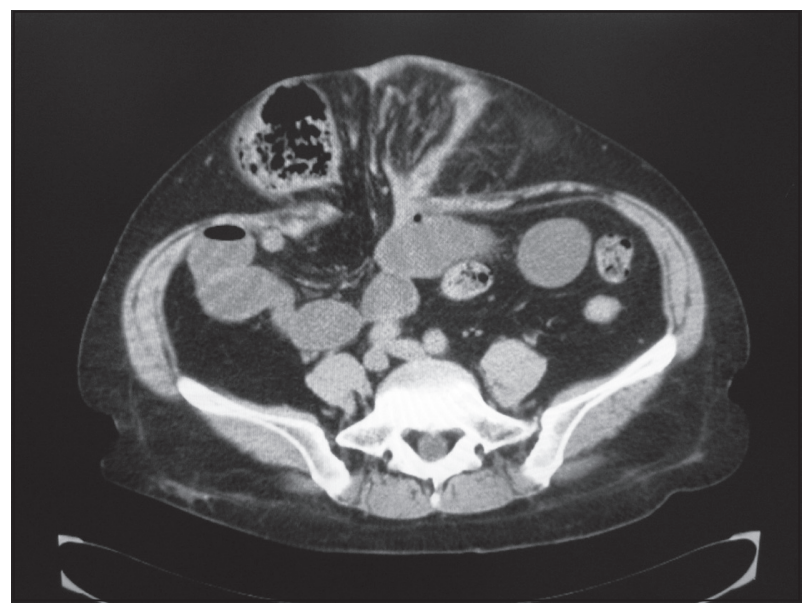

図1 腹部 CT 検査所見

訴に救急外来を受診した。

受診時身体所見：意識は清明で，血圧は175/ $111 \mathrm{mmHg}$, 脈拍は 78 回/分, 呼吸回数は 26 回/分,

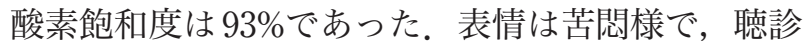
にて呼気は著明に延長し，喘鳴を吸気時および呼気 時ともに全肺野で聴取された。一方，臍上部から下 腹部にかけて約 $15 \times 20 \mathrm{~cm}$ の大きさで臍へルニアは 著明に膨隆し，腹部は全体的に硬く圧痛を認めた。

受診時検査所見：血液生化学検査では, 白血球数 が13,500/ $\mu$ 几上昇していたが，他の所見に異常は なかった。動脈血血液ガス分析は, $\mathrm{PaO}_{2} 65 \mathrm{mmHg}$, $\mathrm{PaCO}_{2} 40 \mathrm{mmHg}, \mathrm{pH} 7.460, \mathrm{BE} 4.2 \mathrm{mmol} / \mathrm{d} l$, $\mathrm{HCO}_{3}^{-} 28.0 \mathrm{mmol} / \mathrm{d} l$ であった。心電図や胸部単純 $\mathrm{X}$ 線写真に異常はなかった。腹部 CT 検査では，巨大 な臍へルニアにおける大量の腸管の脱出を認めた (図1).

受診後の経過：デキサメタゾン $200 \mathrm{mg}$ の静脈内 投与にて, 吸気時の喘鳴は消失し, 呼吸状態の改善 がわずかにみられた。一方，臍へルニアにおいて腸 管は嵌頓の状態であり，用手還納を試みられるも不 可能であった。以上から，喘息発作のコントロール は不十分であるが，イレウスの症状を伴う臍へルニ ア嵌頓の腹部症状を優先して, 緊急手術が施行さ れた。

\section{II 麻酔経過}

前投薬は行わなかった。手術室入室時には，呼気 時にのみ喘鳴を聴取したが，呼吸困難はみられなか つた。入室時の血压は $158 / 98 \mathrm{mmHg}$ ，脈拍は 82 回/分, 呼吸数は 25 回/分, 酸素は $8 \mathrm{l} /$ 分のマスク

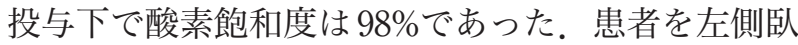
位とし，Th10/11間から硬膜外カテーテルを挿入 した. $2 \%$ ドカインを $2.0 \mathrm{~m} l$ 投与し，〈も膜下腔へ の迷入がないことを確認した。続けて L3/4間から Quincke 25G 針を用いて 0.5\%高比重ブピバカイン $1.7 \mathrm{~m} l$ による脊髄くも膜下麻酔(以下，脊椎麻酔)を 行った。患者を仰臥位とし, 約6分後にピンプリッ ク法にて無痛域がTh8以下であることを確認した。 約 10 分後に，血圧は $110 / 52 \mathrm{mmHg}$, 脈拍は 44 回/ 分へ低下し嘔気も訴えたために，アトロピン $0.5 \mathrm{mg}$ を静脈内投与した。循環動態が安定したところで, ケタミンとプロポフォールの投与を開始した。標準 体重を $50 \mathrm{~kg}$ として算出し, 初めにケタミン $0.5 \mathrm{mg}$ / $\mathrm{kg}$ ，プロポフォール $0.4 \mathrm{mg} / \mathrm{kg}$ を単回投与し，続け てケタミンを $1.0 \mathrm{mg} / \mathrm{kg} / \mathrm{hr}$ で，プロポフォールを $2.0 \mathrm{mg} / \mathrm{kg} / \mathrm{hr}$ でそれぞれ持続投与を開始した。術中 の喘息発作は徐々に軽快し, 呼気時の喘鳴も消失し た. 術中の呼吸回数は20〜25回/分で，鼻腔前に 留置した延長チューブよりモニタリングしたカプノ グラム上の炭酸ガス分压は $35 \sim 39 \mathrm{mmHg}$ であっ た。術中の鎮痛状態は良好であったが，メッシュプ ラグ挿入時にはじめて覚醒し, 痛みを訴えた。ケ夕 ミン $0.5 \mathrm{mg} / \mathrm{kg}$ の単回投与と硬膜外カテーテルから $1 \%$ ドカイン $4.0 \mathrm{~m} l$ を投与したところ，再び鎮痛を 得ることができた。また覚醒に対しては，プロポフ オールを一時的に $3.0 \mathrm{mg} / \mathrm{kg} / \mathrm{hr}$ 一増量して対応し た。手術終了時にケタミン，プロポフォールの投与 を中止し約 10 分後に覚醒した。手術時間 2 時間 10 分, 麻酔管理時間 2 時間 36 分, 出血量 $205 \mathrm{~g}$, 尿量 $1,000 \mathrm{~m} l$, 総輸液量 $1,100 \mathrm{~m} l$, 総ケ夕ミン投与量 $160 \mathrm{mg}$, 総プロポフォール投与量 $350 \mathrm{mg}$ であった。 
手術終了時から硬膜外カテーテルより $0.2 \%$ ロピバ カインを $5.0 \mathrm{ml} / \mathrm{hr}$ で持続投与した。手術室退室時 の無痛域はピンプリック法にてL1以下と確認した が，創部痛は自制内であった。また呼吸状態は安定 しており，喘息発作はみられず，聴診にても喘鳴は 聴取されなかった。

\section{III 術後経過}

呼吸状態はしばらく安定していたが，手術終了後 10 時間後に再び喘息発作が出現した。ツロブテ ロール $2 \mathrm{mg}$ の貼付，デキサメタゾン $200 \mathrm{mg}$ の静脈 内投与，サロメテロール/フルチカゾンの吸入で対 応された。術後 2 日目には術前と同様の処方が再開 されたが，喘息のコントロールは不十分であった。 外科的な合併症は認めず，術後11日目に退院とな つた。

\section{IV 考 察}

全身麻酔に伴う気管挿管や抜管は，気道刺激によ つて喘息発作を誘発しやすいと報告されている ${ }^{2)}$. よってわれわれは，呼吸状態をさらに悪化させない ことを優先し, 自発呼吸を温存した硬膜外麻酔併用 脊椎麻酔法を選択した。

上位胸髄に及ぶ広範囲の交感神経ブロックを伴う 硬膜外麻酔や春椎麻酔では, 喘息発作誘発の可能性 があると考えられており，その施行に関しては賛否 両論がある ${ }^{3)}$ ，自験例では，予定の皮膚切開位置か ら考慮して，最低でも Th6〜8以下の無痛域を得る 必要があった。また交感神経ブロックは，無痛域よ りも頭側に及ぶため ${ }^{4)} に ，$ 自験例における交感神経 ブロックは上位胸髄に及ぶ広範囲になる可能性が高 いと予測された。実際にも，春椎麻酔後の徐脈と血 圧低下を認めており，予測どおりであった。以上か ら，術中における喘息発作の悪化の可能性が考慮さ れたので，そのコントロールと鎮痛補助の目的でケ タミンを，術中のストレスを緩和する鎮静の目的で プロポフォールを，持続投与することとした。
ケタミンは $\beta$ 刺激作用による気管支拡張作用を有 する鎮痛剂である ${ }^{5)}$ ．自験例では，硬膜外麻酔併用 脊椎麻酔によって鎮痛効果を得ていたために，ケ夕 ミンの鎮痛効果は補助的なものと考元，喘息に対す る気管支拡張作用を主な目的として持続投与を行つ た。持続投与量として，垣花ら ${ }^{6)}$ の報告を参考にし て， $0.5 \mathrm{mg} / \mathrm{kg}$ の単回投与後に $1.0 \mathrm{mg} / \mathrm{kg} / \mathrm{hr}$ で持続 投与を開始した。以後，術中の呼吸状態は安定し， 呼気時の喘鳴も徐々に消失し，喘息のコントロール は良好であったと考えられた。また呼吸回数の増加 もなく，カプノグラム上での呼気終末炭酸ガス分圧 の上昇もみられず呼吸状態は安定していた。しかし 自験例での呼気終末炭酸ガス分圧のモニタリング は，鼻孔前に留置した延長チューブからカプノグラ ムで測定したサイドストリーム型の簡易なものであ り正確性にやや欠ける可能性がある。より正確に呼 気終末炭酸ガス分圧の評価を行い，安全に呼吸管理 をするためには，炭酸ガスセンサーがより生体に近 いメインストリーム型 $\left(\mathrm{CO}_{2}\right.$ センサキット ${ }^{\circledR}$ ，日本光 電，東京)のカプノグラムを用いるか動脈血血液ガ ス分析を行うべきであったと考えられた。

一方，術中の鎮痛状態は良好であったが，メッシ ュプラグ挿入時に疼痛を訴えた。このとき，脊椎麻 酔開始時より約 2 時間が過ぎており，手術終了時の 無痛域がL1 以下であったことも考慮すると，この 疼痛は脊椎麻酔による鎮痛効果が減弱したことが原 因であると考えられた。これに対しては，ケ夕ミン の追加投与と硬膜外カテーテルからのリドカインの 追加投与で再度鎮痛効果が得られて対応できたが， 脊椎麻酔の持続時間を考慮したケタミンの持続投与 量の変更や硬膜外カテーテルからの追加投与をある 程度先行して行っておくべきであったと反省させら れた。

また術後の呼吸状態も，手術終了後からの約半日 間であったが，術直前の状態に比べても非常に安定 していた。これはケタミンの代謝産物であるノルケ 夕ミンが比較的長時間一定の濃度で残存し続ける ${ }^{7)}$ 
ことに関係していると考えられ，周術期の喘息コン トロールにおいてケタミンが有用である可能性が高 いことが示唆された。

プロポフォールは，動物実験レベルでは気管支平 滑筋弛緩作用を有する ${ }^{8)}$ と報告されているが，その 機序は明らかではない。自験例では, 呼吸停止を起 こさずに，術中のストレスを緩和する軽度の鎮静を 保つ目的で持続投与を行った。術中の鎮静状態は, メッシュプラグ挿入時に痛みとともに覚醒し一時的 な増量を行った以外には，呼吸抑制もなく良好であ つた。術中の鎮静度はMackenzie ら ${ }^{9}$ による鎮静ス コアの5段階評価で $3 〜 4$ 段階であったと判断した. また鎮静度の評価としての Bispectral index モニ夕 リングは, ケタミン使用下での数值の解釈に注意が

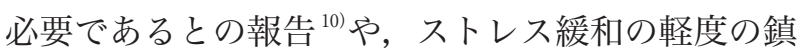
静が目的であったことから, 自験例では施行しなか つた.

最後に, 自験例における静脈麻酔に伴う嘔吐の危 険性に関して考察する。自験例は，臍へルニア嵌頓 によるイレウス症状を認めており，術中の嘔吐，嘔 吐に起因する気道閉塞や誤燕性肺炎発症の危険性に 対しても十分留意する必要があると考えられた。一 般にケタミンは気道分泌を増加させるが, その結果, 気道内の分泌物貯留や舌根沈下によって咳反射が起 こり，嘔吐を誘発することがあると報告されてい る ${ }^{11)}$. 自験例では, 脊椎麻酔後の徐脈発症時にアト ロピンを静脈内投与しており, 結果として気道分泌 が抑制されて咳嗽反射が起こらずに，術中の嘔吐を 誘発しなかった可能性が高いと考えられた。また制 吐作用を有すると考えられているプロポフォール ${ }^{11}$ を併用していたことも, 嘔吐の予防に有用であった と考えられた。しかし，これらの対応だけでは術中 の嘔吐予防に不十分であることもあり, 状況に応じ て経鼻胃管の挿入などの対応も考慮すべきであると 考えられた。

\section{結＼cjkstart語}

喘息発作と腹痛を主訴に救急外来を受診した患者 における緊急手術の麻酔管理で，ケ夕ミンが有用で あった 1 症例を経験した。本麻酔方法は, ケ夕ミン の投与量に再検討の余地はあるものの，広範囲の交 感神経ブロック下でも，その気管支拡張作用によっ て周術期の喘息発作をコントロールすることがで き，また手術が長時間になっても，ケタミンによっ て鎮痛効果も得ることができるために，喘息患者に とって有用であると考えられた。

\section{参考文献}

1）鈴川真穂，大田健：気管支喘息. 綜合臨牀 $57 ： 102-$ 105,2008

2) Kingston HG, Hirshman CA : Perioperative management of the patient with asthma. Anesth Analg 63 : 844-855, 1984

3）藤森貢, 田中経一, 安田勇ほか：硬膜外麻醉。日臨麻 会誌 $10 ： 434-441,1990$

4) Wang CY, Ong GSY : Severe bronchospasm during epidural anaesthesia. Anaesthesia $48: 514-515,1993$

5）海津基生，佐野公人，東里十三雄：塩酸ケ夕ミン微量 点滴投与法の有用性と臨床応用. 歯学 $89 ： 62-65,2002$

6）垣花学, 斎藤俊, 奥田佳朗：喘息発作中の十二指腸潰 瘍穿孔性腹膜炎に対する緊急開腹術の麻酔経験．麻醉 $49: 282-288,2000$

7）高木芳人, 廣田和美，工藤剛ほか：完全静脈麻酔中の ケタミン抒よびノルケタミンの薬物動態に関する臨床 的研究. 基礎と臨床 $29: 4287-4294,1995$

8) Pizov R, Brown RH, Weiss YS, et al. : Wheezing during induction of general anesthesia in patients with and without asthma. A randomized, blinded trial. Anesthesiology 82 : 1111-1116, 1995

9) Mackenzie N, Grant IS : Propofol for intravenous sedation. Anaesthesia $42: 3-6,1987$

10）乶原弘吉, 浅野直子, 岩田敏男ほか：プロポフォール . ケタミン麻酔中のbispectral index, spectral edge frequency 90 と各周波数帯脳波の変動. 麻酔 48 : 611616, 1999

11）植木隆介, 太城力良：麻酔関連のトラブルとその救急 処置. 産婦人科治療 $84: 1042-1048,2002$ 


\title{
Successful Anesthetic Management of a Patient with a Bronchial Asthmatic Attack and Abdominal Pain by Continuous Infusion of Ketamine
}

\author{
Atsushi KOTERA, Seiji KOUZUMA, Naoki MIYAZAKI, \\ Masahiro HASHIMOTO, Kenichiro TAKI, Kimiaki ESAKI \\ Department of Anesthesiology, National Hospital Organization Kumamoto Medical Center
}

A 55-year-old female visited the emergency unit because of a bronchial asthmatic attack and abdominal pain. Though the bronchial asthmatic attack was not well-controlled even after treatment with steroid, an emergent operation for a strangulated umbilical hernia was scheduled. We underwent spinal anesthesia combined with epidural anesthesia, and used continuous infusion of ketamine as a bronchodilator and sub-analgesic, and propofol to reduce the stress during the surgery. After 2.0 $\mathrm{m} l$ of $2 \%$ lidocaine was injected through the epidural catheter, $1.7 \mathrm{ml}$ of $0.5 \%$ hyperbaric bupivacaine was injected for spinal anesthesia, and analgesia up to Th8 was obtained. During the surgery, the bronchial asthmatic attack was well-controlled. About two hours after the beginning of spinal anesthesia, the patient woke up and complained of wound pain. But an additional injection of ketamine and local anesthetic through the epidural catheter were effective for the pain. Though the appropriate dosage of ketamine remains to be elucidated, our anesthetic management was useful for the patient with a bronchial asthmatic attack.

Key Words : Bronchial asthmatic attack, Spinal anesthesia, Epidural anesthesia, Ketamine, Emergency surgery

The Journal of Japan Society for Clinical Anesthesia Vol.30 No.5, 2010 